\title{
TOGGLE CLAMP FOR RUBBER TENSILE SPECIMENS
}

\author{
By William L. Holt and Archibald T. McPherson
}

\section{ABSTRACT}

The new toggle clamp is an adaptation of the familiar wedge grips used for metal specimens, and consists essentially of parallel blocks, each carried on two short links in such a way that a rubber specimen placed between the blocks is gripped more tightly the greater the pull. The clamp was designed primarily for tubular specimens of electrical insulation, but is equally applicable to specimens in the form of strips or dumbbells. Insulation from No. 14 Performite wire tested with the new clamp showed values of the tensile strength approximately 20 percent higher and ultimate elongation 10 percent higher than with the roll clamp. Insulation from ignition cable having a wall 0.1 inch in thickness showed a tensile strength 50 percent higher and an ultimate elongation 18 percent higher with the toggle than with a roll clamp. Tubular or strip specimens tested with the toggle clamp gave values of the tensile strength of the order of only 5 percent lower than obtained with dumbbells of the same composition. Specimens breaking in the clamps, whether roll or toggle, gave a symmetrical distribution of values about the mode, while those breaking between the clamps showed a skew distribution. The coefficient of variation did not vary significantly with the type of clamp or shape of specimen, the numerical values ranging from 0.043 to 0.060 for tensile strength and from 0.017 to 0.035 for ultimate elongation.

\section{CONTENTS}

I. Introduction

II. Description of clamp

III. Results of tests

1. Tests of No. 14 Performite insulation

2. Tests of insulation from ignition cable

3. Tests of flat sheets

IV. Interpretation of results

1. Comparison of roll and toggle clamps for tubular specimens_... 549

2. Comparison of strip and tube, with dumbbell specimens . . . . 550

3. Significance of the position of break $\ldots \ldots \ldots 1$

4. Coefficient of variation

V. Summary and conclusion

\section{INTRODUCTION}

One of the major problems in the tensile testing of rubber has to do with the application of uniform stress to the cross section of the specimen. While the definition of tensile strength stipulates that the stress shall be uniform, this condition is never fully realized in practice on account of localized stresses set up in attaching the specimens to the testing machine. Two general means are used to minimize these local stresses and secure a reasonably uniform tensile stress in the portion of the specimen under observation. One is by the use of test pieces having enlarged ends, such as the familiar dumbbell specimen, and the other is by the employment of clamps which distribute the clamping stresses over an area of the test piece which is relatively large in comparison to the cross section. 
The lack of uniform stress distribution in the case of the dumbbell is shown by the fact that such specimens break most frequently in the curved portion just outside the gage marks, where the cross section is somewhat greater than in the central constricted portion. ${ }^{1}$ This concentration of stresses in the fillet is readily demonstrated by photoelastic observations on transparent specimens.

When specimens of uniform cross section, such as insulation or tubing, are tested with the usual clamp of the roll type, failure occurs most frequently in the "bite," and the values obtained for the tensile

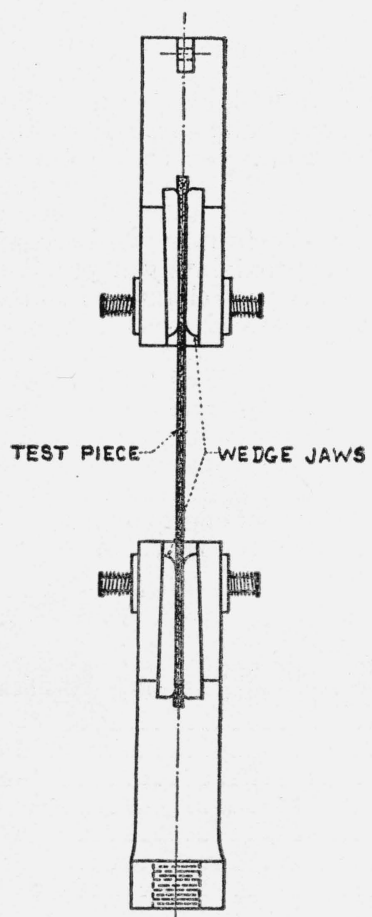

Figure 1.- Simplex wedge clamps. strength and the ultimate elongation may be considerably lower than those found from dumbbell specimens of the same composition.

In order to obtain more satisfactory results with tubular specimens, the Simplex Wire and Cable Co. has developed a clamp ${ }^{2}$ similar to the familiar wedge grips for metal specimens. As shown in figure 1, it consists of wedges which slide against surfaces inclined at such an angle that the faces of the wedges are parallel. The test piece is, therefore, gripped so as to distribute the clamping stresses over a relatively large area.

\section{DESCRIPTION OF CLAMP}

The present clamp, which is shown in figure 2, was developed from the Simplex clamp, and differs from it essentially in that each of the two blocks which grip the specimen is carried on two short links or toggle levers. These links, which are 2 inches long, are bronze castings and are mounted by means of one-half inch pins on a $5 / 16$-inch steel base plate. The faces of the clamping blocks are $3 / 4$ inch wide and $1 \frac{1}{2}$ inches long, with top and bottom edges rounded. Guides in the back of the blocks keep them in the proper juxtaposition at all times. Light springs tend to keep the clamps in the closed position.

Advantages of this clamp over the Simplex clamp are its adaptability to a greater range of sizes of specimens, and the facility with which specimens can be inserted and removed.

\section{RESULTS OF TESTS}

Since the clamps were intended primarily for rubber insulation, they were tried out with specimens from about a dozen different sizes and types of wire and cable. The clamps appeared to be equally satisfactory for sizes ranging from No. 18 to No. 6, American Wire Gage, and for compositions from "latex" rubber to "30-percent" and

\footnotetext{
${ }^{1}$ Report of Physical Testing Committee, Ind. Eng. Chem. 17, 535 (1925).
}

2 Private communication to the author. 


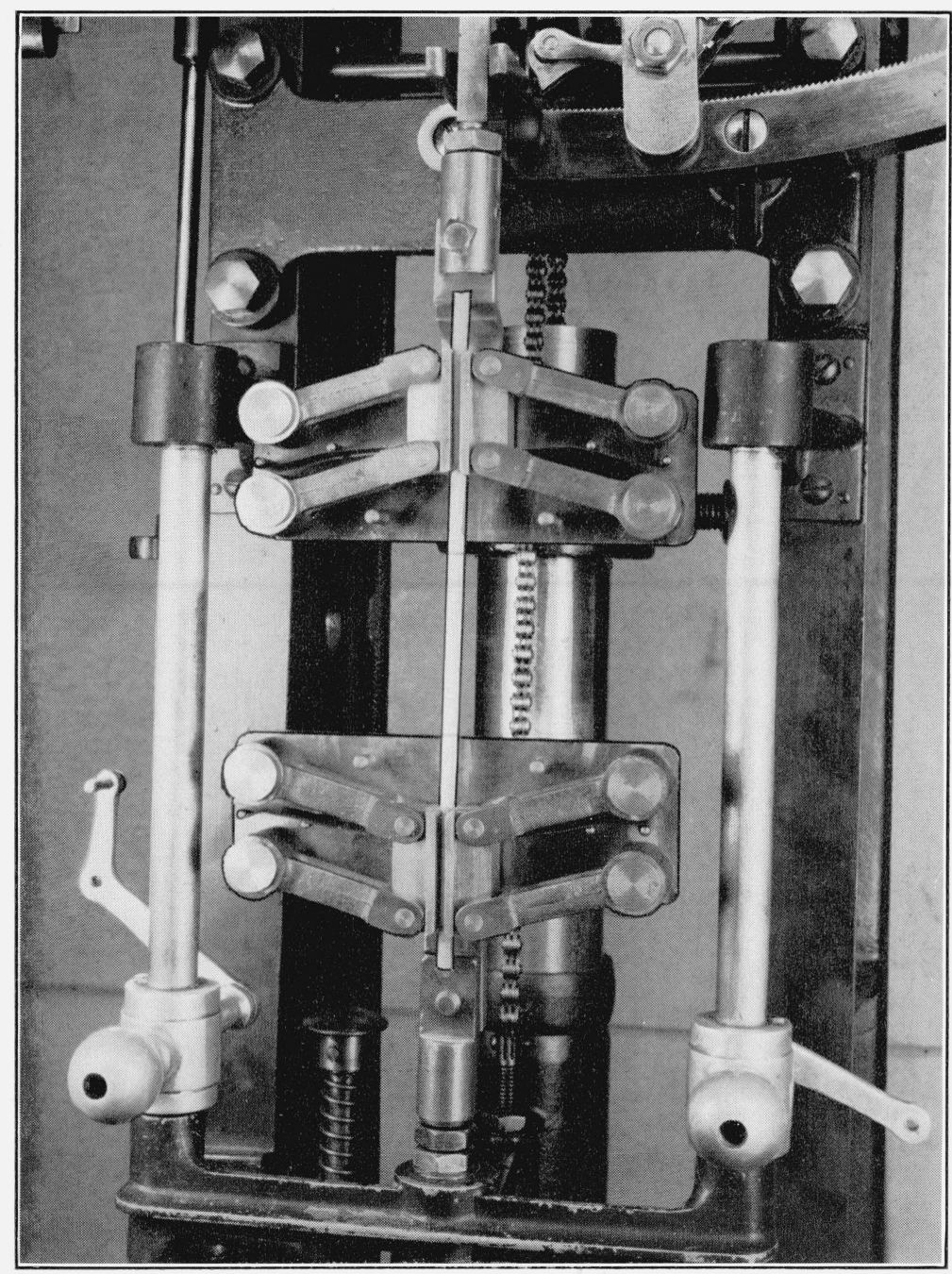

FIGURE 2.-Toggle clamps mounted in tensile-test machine. 


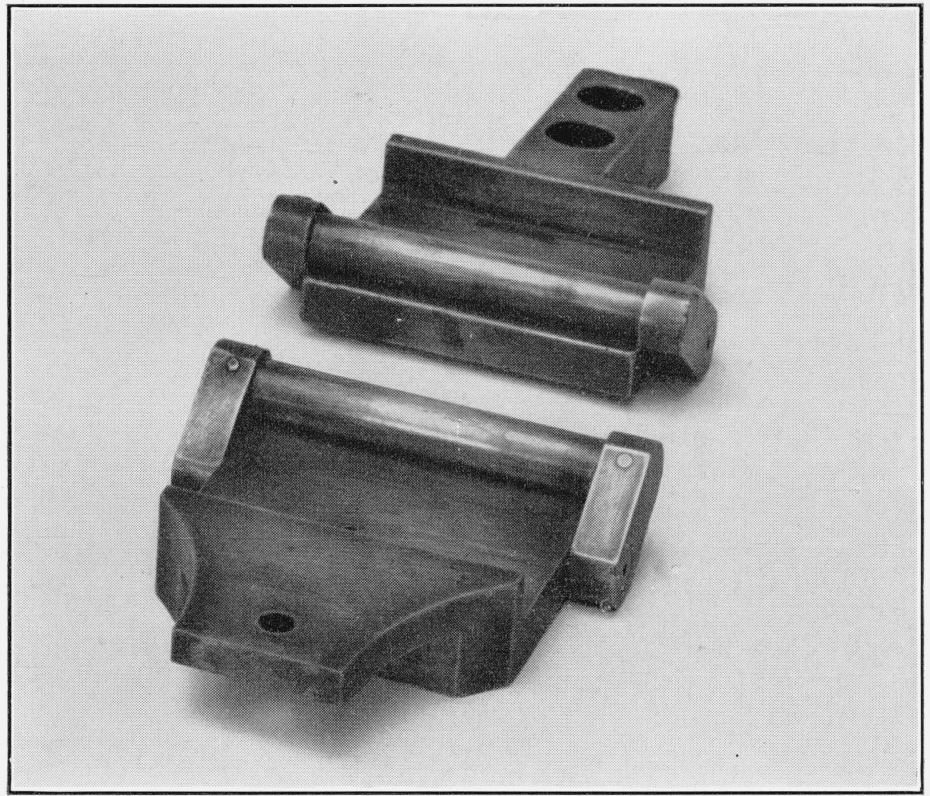

Figure 3.-Roll clamps. 
"code" compounds. The breaking loads observed ranged from about 5 to 125 pounds.

Difficulty was encountered only in the case of specimens having a wax finish. These specimens sometimes slipped through the clamps. This difficulty could, in most cases, be remedied by wiping the specimens with a cloth moistened with acetone or simply by scrubbing them. with pumice soap and water.

More extensive tests were also made on two samples of insulation for the purpose of comparing the new clamp with the usual clamp of the roll type. The satisfactory character of the results obtained with tubular specimens of insulation suggested the possibility of extending the use of the new clamps to specimens in the form of strips. Accordingly, tests were made on strip specimens cut from sheet material, comparison being made with dumbbell specimens cut from the same material.

In computing the results of tests, the standard deviation was found for all sets of determinations. The standard deviation is defined as "the square root of the mean of the squares of the deviations of all the observations," the deviation being "the difference between an observation and the mean of all the observations." "3

\section{TESTS OF NO. 14 PERFORMITE INSULATION}

A number of tests were conducted on insulation from No. 14 AWG Performite wire for the purpose of making a statistical comparison of the performance of the new clamp with that of a conventional roll clamp. The latter was of the design shown in figure 3, and was provided with a roll $3 / 8$ inch in diameter. Approximately 120 tubular test pieces, each 6 inches long, were prepared from one continuous length of wire. Alternate specimens were taken for tests with the respective clamps in order to eliminate the effect of any variation along the length of the sample. The wall thickness of the insulation was nominally $3 / 64$ inch. The cross-sectional area of specimens was found from measurements of the diameter of the conductor and the external circumference of the insulated wire. The tensile measurements were made in the usual way by means of a Scott testing machine for rubber.

The results are summarized in table 1 and are shown in the form of histograms in figure 4 . Two salient differences between the results obtained with the respective clamps are evident from the histograms. In the first place, the values for the tensile strength and the ultimate elongation obtained with the toggle clamp are significantly higher than those obtained with the roll clamp. In the second place, the values obtained with the roll clamp are symmetrically distributed about the mode (the value of most frequent occurrence), while those obtained with the toggle clamp give rise to a skew-shaped distribution curve with a larger range of values below the mode than beyond it.

All of the specimens tested with the roll clamp broke in the "bite" between the roll and the base plate. In the case of the toggle clamp however, 9 specimens broke in the clamp and 50 in the "clear." Of the latter, 35 breaks were between the gage marks and 15 were in the

\footnotetext{
${ }^{8}$ E. S. Pearson, The Application of Statistical Methods to Industrial Standardization and Quality Control, p. 109, British Standards Institution, London (1935).
} 
lengths between the gage marks and the clamps. The results were classified according to the position of break and analyzed as shown in table 2. The differences between the three groups are not large

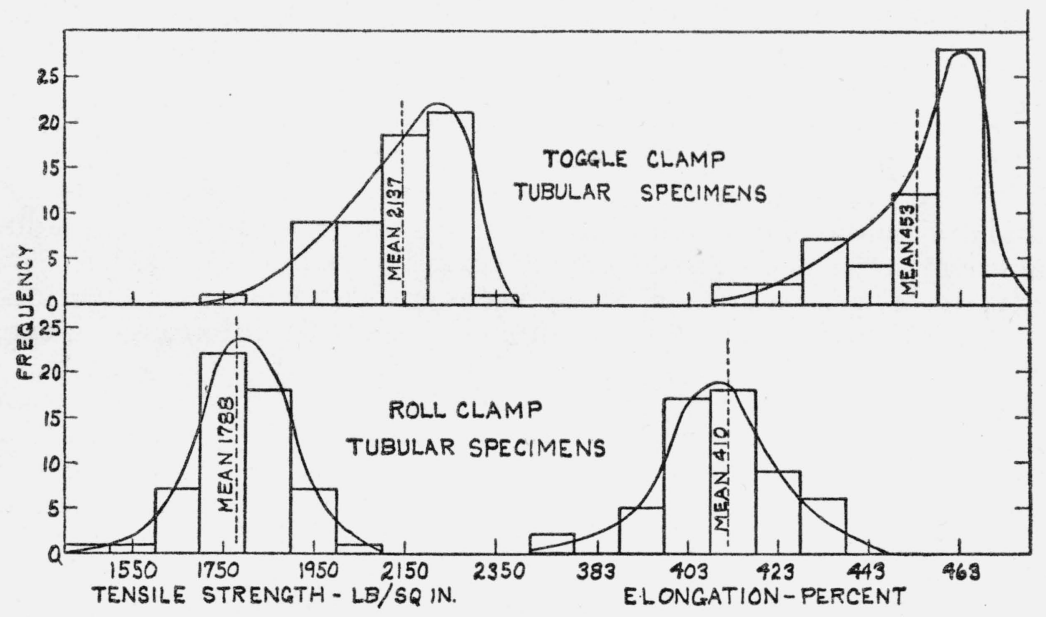

FIgURE 4.-Histograms of tensile properties of insulation from No. 14 Performite wire.

enough to be significant. The matter will be discussed subsequently in connection with comparable observations on other samples.

Table 1.-Comparative tests of No. 14 P rformite insulation with toggle and with roll clamp

\begin{tabular}{|c|c|c|c|c|}
\hline \multirow{2}{*}{ Measurement } & \multicolumn{2}{|c|}{ Tensile Strength } & \multicolumn{2}{|c|}{ Ultimate Elongation } \\
\hline & Toggle clamp & Roll clamp & Toggle clamp & Roll clamp \\
\hline $\begin{array}{l}\text { Range } \\
\text { Mean } \\
\text { Standard deviation }\end{array}$ & $\begin{array}{r}\text { lb/in. } .^{2} \\
1,790 \text { to } 2,300 \\
2,137 \\
117\end{array}$ & $\begin{array}{r}\text { lb/in. } \\
1,460 \text { to } 2,010 \\
1,788 \\
95\end{array}$ & $\begin{array}{r}\% \\
415 \text { to } 470 \\
453 \\
14\end{array}$ & $\begin{array}{r}\% \\
375 \text { to } 440 \\
410 \\
14\end{array}$ \\
\hline
\end{tabular}

TABLE 2.-Relation between position of break and tensile properties of No. 14 Performite insulation tested as tubular specimens with toggle clamp

\begin{tabular}{|c|c|c|c|}
\hline & \multicolumn{3}{|c|}{ Position of break } \\
\hline & In clamps & $\begin{array}{l}\text { Within gage } \\
\text { marks }\end{array}$ & $\begin{array}{l}\text { Between clamps } \\
\text { and gage marks }\end{array}$ \\
\hline Number of specimens...- & 9 & 35 & 15 \\
\hline $\begin{array}{l}\left.\text { Tensile strength (lb/in. }{ }^{2}\right) \text { : } \\
\text { Range } \\
\text { Mean } \\
\text { Standard deviation. }\end{array}$ & $\begin{array}{r}1,900 \text { to } 2,300 \\
2,130 \\
120\end{array}$ & $\begin{array}{r}2,190 \text { to } 2,290 \\
2,152 \\
110\end{array}$ & 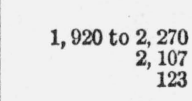 \\
\hline $\begin{array}{l}\text { Ultimate elongation (\%): } \\
\text { Range } \\
\text { Mean } \\
\text { Standard deviation. }\end{array}$ & $\begin{array}{r}423 \text { to } 465 \\
451 \\
15\end{array}$ & $\begin{array}{r}415 \text { to } 470 \\
455 \\
13\end{array}$ & $\begin{array}{r}420 \text { to } 470 \\
449 \\
15\end{array}$ \\
\hline
\end{tabular}




\section{TESTS OF INSULATION FROM IGNITION CABLE}

Another series of comparative tests was made on samples of an ignition cable in which the ratio of wall thickness of insulation to conductor diameter was relatively large, the thickness of the wall being approximately 0.1 inch and the diameter of the conductor 0.035 inch. These dimensions were such that it was possible to prepare small dumbbell specimens having a constricted portion $1 / 8$ inch in width.

Four different lengths of the ignition cable were used, and were regarded as different samples. They were taken from different shipments furnished by the same manufacturer under Navy Department Specification M-216b. Three lots of test pieces were prepared from each sample-one lot of dumbbell specimens and two lots of tubular specimens, one for each of the two types of clamps. The tensile determinations were made in the usual way. A Scott testing machine was employed for the tubular specimens, but it was necessary to use a spring-balance machine of lower range for the dumbbell specimens, since the latter had a relatively small cross section. Roll clamps were used for the dumbbell specimens, but the type of clamp was not a matter of consequence in this case, since none of the dumbbells broke in the clamp.

TABLE 3.-Effect of type of clamp and test piece on tensile properties of the insulation of 4 samples of ignition cable

TENSILE STRENGTH

\begin{tabular}{|c|c|c|c|c|c|c|c|}
\hline $\begin{array}{l}\text { Shape of } \\
\text { specimen }\end{array}$ & Clamp & Measurement & Sample 1 & Sample 2 & Sample 3 & Sample 4 & $\begin{array}{l}\text { Aver- } \\
\text { age of } \\
\text { four } \\
\text { sam- } \\
\text { ples }\end{array}$ \\
\hline $\begin{array}{l}\text { Dumbbell.- } \\
\text { Tubular.-- } \\
\text { Do }\end{array}$ & $\begin{array}{l}\text { Roll }{ }^{1}-. . \\
\text { Toggle.. } \\
\text { Roll }\end{array}$ & $\begin{array}{l}\text { Range }{ }^{2}- \\
- \text { do }\end{array}$ & $\begin{array}{c}\text { lb/in. }{ }^{2} \\
2,830 \text { to } 3,310 \\
2,860 \text { to } 3,430 \\
2,000 \text { to } 2,460\end{array}$ & $\begin{array}{c}\text { lb in } .^{2} \\
3,220 \text { to } 3,750 \\
3,070 \text { to } 3,300 \\
2,050 \text { to } 2,650\end{array}$ & $\begin{array}{c}\text { lb/in } .^{2} \\
2,960 \text { to } 3,530 \\
2,430 \text { to } 3,260 \\
1,480 \text { to } 2,105\end{array}$ & $\begin{array}{c}\text { lb/in. } .^{2} \\
3,090 \text { to } 3,730 \\
3,100 \text { to } 3,390 \\
1,515 \text { to } 2,320\end{array}$ & lb/in. ${ }^{2}$ \\
\hline $\begin{array}{r}\text { Dumbbell_. } \\
\text { Tubular.-- } \\
\text { Do.-.- }\end{array}$ & $\begin{array}{l}\text { Roll 1-. } \\
\text { Toggle. } \\
\text { Roll }\end{array}$ & $\begin{array}{l}\text { Mean } \\
\text { do }\end{array}$ & $\begin{array}{l}3,130 \\
3,220 \\
2,227\end{array}$ & $\begin{array}{l}3,572 \\
3,195 \\
2,395\end{array}$ & $\begin{array}{l}3,224 \\
2,880 \\
1,845\end{array}$ & $\begin{array}{l}3,458 \\
3,258 \\
1,900\end{array}$ & $\begin{array}{l}3,344 \\
3,138 \\
2,091\end{array}$ \\
\hline Dumbbell_. & Roll 1... & $\begin{array}{c}\text { Standard de- } \\
\text { viation. }\end{array}$ & 141 & 137 & 136 & 186 & 150 \\
\hline $\begin{array}{r}\text { Tubular... } \\
\text { Do..-- }\end{array}$ & $\begin{array}{l}\text { Toggle. - } \\
\text { Roll }\end{array}$ & - do & $\begin{array}{l}135 \\
138\end{array}$ & $\begin{array}{r}74 \\
154\end{array}$ & $\begin{array}{l}244 \\
184\end{array}$ & $\begin{array}{r}72 \\
237\end{array}$ & $\begin{array}{l}131 \\
178\end{array}$ \\
\hline
\end{tabular}

ULTIMATE ELONGATION

\begin{tabular}{|c|c|c|c|c|c|c|c|}
\hline $\begin{array}{l}\text { Dumbbell. } \\
\text { Tubular... } \\
\text { Do }\end{array}$ & $\begin{array}{l}\text { Roll 1-.-- } \\
\text { Toggle.- } \\
\text { Roll }\end{array}$ & $\begin{array}{l}\text { Range }^{2} \\
\text { do }\end{array}$ & $\begin{array}{c}\% \\
580 \text { to } 620 \\
590 \text { to } 640 \\
510 \text { to } 565\end{array}$ & $\begin{array}{c}\% \\
575 \text { to } 610 \\
605 \text { to } 620 \\
510 \text { to } 560\end{array}$ & $\begin{array}{c}\% \\
560 \text { to } 610 \\
550 \text { to } 620 \\
465 \text { to } 535\end{array}$ & $\begin{array}{c}\% \\
560 \text { to } 620 \\
605 \text { to } 635 \\
455 \text { to } 535\end{array}$ & $\begin{array}{l}\% \\
\% \\
\end{array}$ \\
\hline $\begin{array}{l}\text { Dumbbell. } \\
\text { Tubular } \\
\text { Do }\end{array}$ & $\begin{array}{l}\text { Roll }{ }^{1}-. \\
\text { Toggle.- } \\
\text { Roll }\end{array}$ & Mean & $\begin{array}{l}604 \\
621 \\
537\end{array}$ & $\begin{array}{l}602 \\
612 \\
545\end{array}$ & $\begin{array}{l}586 \\
593 \\
501\end{array}$ & $\begin{array}{l}596 \\
620 \\
496\end{array}$ & $\begin{array}{l}597 \\
612 \\
520\end{array}$ \\
\hline Dumbbell. & Roll 1... & Standard de- & 10 & 10 & 10 & 10 & 10 \\
\hline $\begin{array}{l}\text { Tubular... } \\
\text { Do } \ldots . . . .\end{array}$ & $\begin{array}{l}\text { Toggle.. } \\
\text { Roll }\end{array}$ & - do & $\begin{array}{l}12 \\
16\end{array}$ & $\begin{array}{r}5 \\
13\end{array}$ & $\begin{array}{l}21 \\
20\end{array}$ & $\begin{array}{r}9 \\
23\end{array}$ & $\begin{array}{l}12 \\
21\end{array}$ \\
\hline
\end{tabular}

1 The type of clamp used with the dumbbell specimens is not significant since none of the specimens broke in the clamp.

2 There were from 13 to 20 specimens in each group of which the rang e is given.

The results of tests on the four samples of ignition cable are shown in table 3. Values for the tensile strength and the ultimate elongation obtained from tubular specimens tested with the toggle clamp are of the same order of magnitude as those obtained with dumbbell specimens, while values obtained with the tubular specimens in the roll clamp are much lower. 
In the case of sample 1, the tensile strength obtained with dumbbell specimens was a little lower than that obtained with tubular specimens in the toggle clamp, while in the other three cases it was a little higher. The elongation, however, was slightly higher for all samples when tested in the tubular form with the toggle clamp than when tested as dumbbells.

\section{TESTS OF FLAT SHEETS}

Further information regarding the relation between dumbbell and straight specimens was obtained by a series of tests in which a comparison was made between strips and dumbbells cut from the same

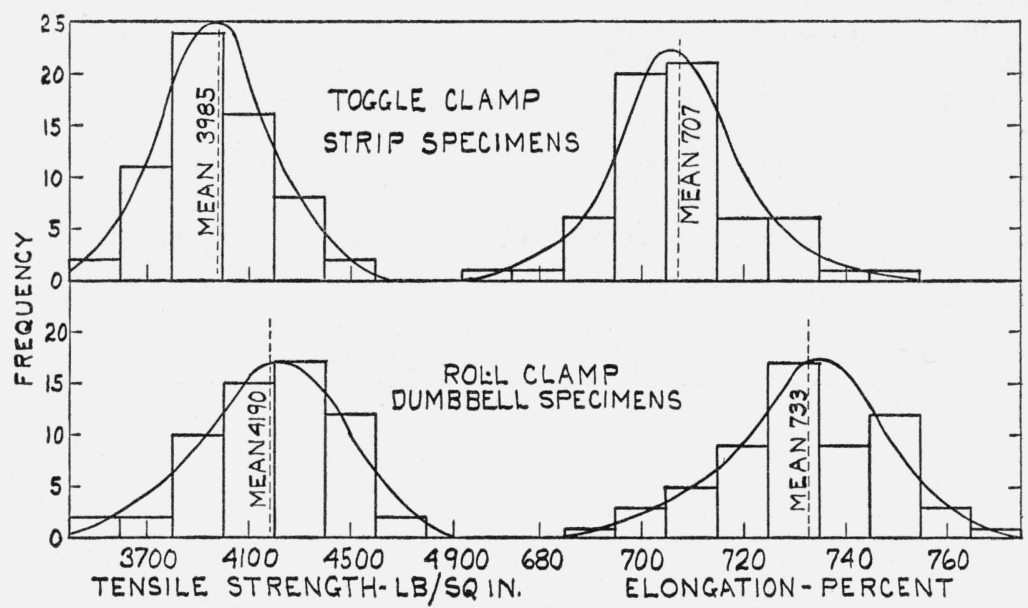

FIGURE 5.-Histograms of tensile properties of strip and dumbbell specimens cut from sheets of a carbon-black compound.

press-cured sheets. The rubber compound used for this work was rade according to the following formula:

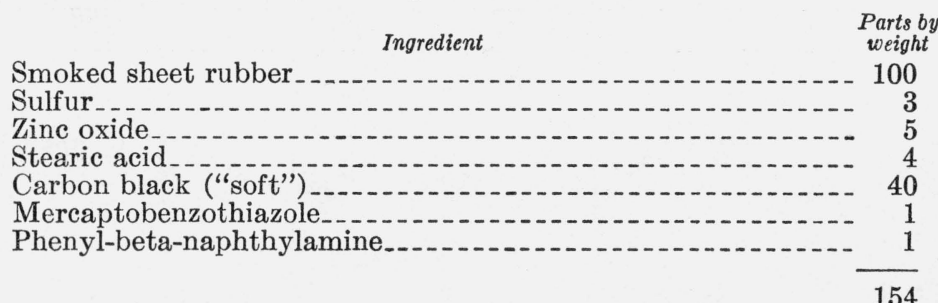

154

Sheets 0.060 to 0.080 inch in thickness were cured for 35 minutes at $259^{\circ} \mathrm{F}$. The strips were 6 inches long and $1 / 4$ inch wide, while the dumbbells were the same length and $1 / 4$ inch wide in the constricted portion and 1 inch wide at the ends. Sixty test pieces of each type were prepared, being cut in approximately equal numbers from each test sheet so as to minimize the effect of any variation from one sheet to another.

The results of tensile tests are summarized in table 4 , and are shown in histograms in figure 5. Both the tensile strength and the ultimate 
elongation obtained with the dumbbell specimens were slightly higher than with the strip specimens, the difference being 5 percent in tensile strength and 3 percent in percentage of the ultimate elongation.

TABLE 4.-Comparative tests of strip and dumbbell specimens from flat sheets

\begin{tabular}{|c|c|c|c|c|}
\hline \multirow[b]{2}{*}{ Measurement } & \multicolumn{2}{|c|}{ Tensile strength } & \multicolumn{2}{|c|}{ Ultimate elongation } \\
\hline & $\underset{\substack{\text { Dumbbell spec- } \\
\text { imen }}}{\mid}$ & $\begin{array}{l}\text { Strip specimen } \\
\text { (with toggle } \\
\text { clamp) }\end{array}$ & $\begin{array}{l}\text { Dumbbell } \\
\text { specimen }\end{array}$ & $\begin{array}{l}\text { Strip speci- } \\
\text { men (with } \\
\text { toggle clamp) }\end{array}$ \\
\hline $\begin{array}{l}\text { Range } \\
\text { Mean } \\
\text { Standard deviation }\end{array}$ & $\begin{array}{r}l b_{\text {/ }} \text { in } .^{2} \\
3,520 \text { to } 4,660 \\
4,190 \\
253\end{array}$ & $\begin{array}{r}l b / \text { in }^{2} \\
3,460 \text { to } 4,460 \\
3,985 \\
213\end{array}$ & $\begin{array}{rr}\% & \\
690 \text { to } 780 \\
733 \\
18\end{array}$ & $\begin{array}{r}\% \\
670 \text { to } 750 \\
707 \\
15\end{array}$ \\
\hline
\end{tabular}

The tests with each type of specimen were classified according to the position of break, as shown in table 5. In the case of the dumbbell specimens, 19 broke between the gage marks and 42 in the fillet just outside the gage marks. Of the strip specimens, 25 broke between the clamps and 38 in the clamps.

TABLE 5.-Relation between position of break and tensile properties of strip and dumbbell specimens

\begin{tabular}{|c|c|c|c|c|}
\hline & \multicolumn{4}{|c|}{ Position of break } \\
\hline & \multicolumn{2}{|c|}{ Dumbbell specimens } & \multicolumn{2}{|c|}{ Strip specimens } \\
\hline & $\begin{array}{c}\text { Between gage } \\
\text { marks }\end{array}$ & In fillet & $\begin{array}{l}\text { Outside } \\
\text { clamps }\end{array}$ & In clamps \\
\hline Number of specimens..... & 19 & 42 & 25 & 38 \\
\hline Tensile strength (lb/in. $\left.{ }^{2}\right):$ & & & & 000 \\
\hline Range & $\begin{array}{r}3,830 \text { to } 4,600 \\
4,178\end{array}$ & $\begin{array}{r}3,520 \text { to } \begin{array}{r}4,660 \\
4,196\end{array}\end{array}$ & $\begin{array}{r}3,800 \text { to } \begin{array}{r}4,370 \\
4,055\end{array}\end{array}$ & $\begin{array}{r}3,460 \text { to } 4,460 \\
3,939\end{array}$ \\
\hline Standard deviation & & 265 & 163 & \\
\hline $\begin{array}{l}\text { Ultimate elongation (\%): } \\
\text { Range... } \\
\text { Mean } \\
\text { Standard deviation }\end{array}$ & $\begin{array}{r}700 \text { to } 760 \\
733 \\
15\end{array}$ & $\begin{array}{r}690 \text { to } 780 \\
733 \\
19\end{array}$ & $\begin{array}{r}680 \text { to } 740 \\
711 \\
14\end{array}$ & $\begin{array}{r}670 \text { to } 750 \\
704 \\
15\end{array}$ \\
\hline
\end{tabular}

\section{INTERPRETATION OF RESULTS}

\section{COMPARISON OF ROLL AND TOGGLE CLAMPS FOR TUBULAR SPECIMENS}

The results of the tests of rubber insulation show that the toggle clamps give significantly higher values for the tensile strength and ultimate elongation than the usual roll clamps. The comparisons made in tables 1, 2, and 4 are shown on a percentage basis in table 6 . In the case of the insulation from the No. 14 Performite wire, the toggle clamps gave a 20 percent higher value for the tensile strength and a 10 percent higher value for the ultimate elongation than did the roll clamp. The thicker insulation from the ignition cable showed a 50 percent greater tensile strength and an 18 percent greater elongation when tested with the toggle clamp than with the 
roll clamp. The discrepancy between the two clamps, therefore, is not constant but appears to increase with the thickness of the specimen.

In the case of the roll clamp, the concentration of stresses in the clamp has a great deal to do with the rupture of the test specimen, as evidenced by the fact that all specimens tested broke in the clamp. Two factors contribute to this effect (1) compressional forces between the roll and the base plate, and (2) the greater elongation to which the outer circumference of the specimen is subjected when it is bent over the roll. The latter circumstance would be expected to result in a decrease in tensile strength with increase in the thickness of the specimen.

TABLE 6.-Effect of type of clamp and shape of specimen on tensile properties and coefficient of variation

\begin{tabular}{|c|c|c|c|c|c|c|}
\hline \multirow[b]{2}{*}{ Sample } & \multirow[b]{2}{*}{ Clamp } & \multirow[b]{2}{*}{ Shape of specimen } & \multirow{2}{*}{$\begin{array}{c}\text { Rela- } \\
\text { tive } \\
\text { tensile } \\
\text { strength }\end{array}$} & \multirow{2}{*}{$\begin{array}{l}\text { Rela- } \\
\text { tive } \\
\text { ulti- } \\
\text { mate } \\
\text { elonga- } \\
\text { tion }\end{array}$} & \multicolumn{2}{|c|}{$\begin{array}{l}\text { Coefficient of } \\
\text { variation }\end{array}$} \\
\hline & & & & & $\begin{array}{l}\text { Tensile } \\
\text { strength }\end{array}$ & $\begin{array}{l}\text { Ultimate } \\
\text { elonga- } \\
\text { tion }\end{array}$ \\
\hline $\begin{array}{l}\text { Insulation from No. } 14 \text { Per- } \\
\text { formite wire. }\end{array}$ & $\left\{\begin{array}{l}\text { Roll } \\
\text { Toggle... }\end{array}\right.$ & Tubular & $\begin{array}{l}100 \\
119.5 \\
100\end{array}$ & $\begin{array}{l}100 \\
110.5 \\
100\end{array}$ & $\begin{array}{r}0.053 \\
.054 \\
088\end{array}$ & $\begin{array}{r}0.034 \\
.031 \\
.035\end{array}$ \\
\hline Insulation from ignition cables. & Toggle & Small dumbhell & 150 & 118 & .043 & .019 \\
\hline $\begin{array}{l}\text { Sheet of carbon black com- } \\
\text { pound. }\end{array}$ & $\left\{\begin{array}{l}\text { Toggle } \\
\text { Roll } 1 \ldots\end{array}\right.$ & Strip & $\begin{array}{l}160 \\
100 \\
105\end{array}$ & $\begin{array}{l}115 \\
100 \\
103.5\end{array}$ & $\begin{array}{l}.048 \\
.054 \\
.060\end{array}$ & .021 \\
\hline
\end{tabular}

1 The type of clamp used with the dumbbell specimens is not significant, since none of the specimens broke in the clamp.

The variations among the results of tests on four different samples of ignition cable indicate that, even when the size and type of specimen are kept the same, the ratio between tests with the two types of clamps is by no means constant. For example, when the tensile strength, as determined by the roll clamp is taken as 100 , the values obtained by means of the toggle clamp were found to range from 139 to 170 , with an average value of 150 , as shown in table 6 ; similarly, taking the ultimate elongation with the roll clamp as 100, the elongations given by the toggle-clamp range from 111 to 125 , with an average value of 118.

\section{COMPARISON OF STRIP AND TUBE, WITH DUMBBELL SPECIMENS}

The results summarized in table 6 indicate that the tensile strength shown by a dumbbell specimen is slightly higher than that given by a tubular or strip specimen of the same composition. This difference amounts to about 7 percent, on the average, for the four samples of ignition cable, and to about 5 percent for the sheet sample of the compound containing "soft" carbon. It would be expected that this difference in tensile strength would be accompanied by a corresponding difference in the ultimate elongation. In the case of the dumbbells and strips cut from the sheet material, the dumbbells gave the greater elongation, by about 4 percent of the total elongation. In the case of the ignition cable, however, the reverse was observed, the ulti- 
mate elongation of the tubular specimens being about 2.5 percent greater than that of the dumbbells.

The present results do not warrant any precise statement as to the relation between results obtained with dumbbells and with strip or tubular specimens. For many practical purposes, however, it appears that the latter specimens can be satisfactorily employed when it is not practical to obtain dumbbells.

\section{SIGNIFICANCE OF THE POSITION OF BREAK}

The rupture of a specimen in a tensile test is likely to start at some point where the stresses are concentrated on account of the shape of the specimen or the means used for clamping it. If rupture does not occur at one of these points of concentrated stresses, it will start at some flaw or inhomogeneity in the rubber. In the latter case, higher values of the tensile strength and ultimate elongation are usually obtained than in the former case, and it is observed that the distribution of values is altered from a symmetrical distribution about the mode to a skew-shaped distribution with a larger range of values below the mode than above it. Such a skew-shaped distribution curve is consistent with the usual explanation that the presence of inhomogeneities alters the observed values of tensile strength and ultimate elongation in such a way as to give rise to a preponderance of lower values, as compared with the symmetrical curve of random distribution.

The fact that all the straight and tubular specimens tested with the roll clamp broke in the "bite" indicates that in this case the concentration of stresses in the clamps is a predominating factor. Consequently a symmetrical distribution of values about the mode would be expected and such is clearly shown by figure 4 .

With the toggle clamp the test piece is gripped over a relatively large area so that the clamping stresses are correspondingly low. Consequently a proportionately larger number of the breaks are initiated by inhomogeneities in the rubber and hence occur out.ide the clamps. In the case of Performite insulation, which contained a relatively coarse filler, only 9 of the 59 breaks occurred in the clamps. With strip specimens made from a carbon-black compound, the relation was reversed and 38 out of 63 specimens broke in the clamps.

The curves which represent the distribution of values of tensile strength and ultimate elongation of Performite insulation, as determined with the toggle clamp, are markedly skewed, as shown by figure 4. On the other hand, the corresponding curves for the strip specimens of the carbon-black compound, as shown in figure 5, are not significantly skewed. This difference in the distribution of values for the two samples is consistent with the differences in the positions at which the respective specimens broke, but the number of observations is not sufficient to warrant a close analysis.

In the case of dumbbell specimens the majority of breaks occurred, as would be expected, in the fillet just outside the gage marks. The results shown in table 5 indicate that there is no large practical difference in tensile properties associated with the position of break, and consequently no reason for discarding the results of all determinations in which specimens break outside the gage marks, as is sometimes done. 
The specimens of Performite insulation which broke outside the clamps were divided into two groups, depending on whether the break was inside or outside the 2 -inch gage length that was employed for measurement of the elongation. As shown in table 2, the average values for these groups do not differ greatly from each other or from the average values of determinations in which the specimens broke in the clamps.

The position of break was observed to have a significant effect on the tensile properties only in the case of the strip specimens of the carbon-black compound shown in table 5. The specimens which broke in the "clear" showed on the average a 3-percent higher tensile strength than those which broke in the clamps. The ultimate elongation of specimens which broke outside the clamps was also slightly greater than that of specimens breaking within the clamps.

\section{COEFFICIENT OF VARIATION}

In order to determine whether the new clamp gave a spread of values different from that obtained with other clamps, the coefficient of variation (ratio of the standard deviation to the mean) was computed for the determinations given in tables 1, 2, 3, and 4. The results which are shown in table 6 indicate that except for one set of tests the coefficient of variation was not significantly influenced by either the type of clamp or the shape of the specimen. The coefficient for tensile-strength tests lies between 0.043 and 0.060 , except for the test of tubular specimens of ignition cable in the roll clamp, when it is 0.088. A coefficient of about 0.05 is usual for tensile-strength measurements on rubber. The coefficient of variation for the measurements of ultimate elongation lies between 0.017 and 0.035 , this range being of usual magnitude. The tests of ignition cable which showed the greatest spread in tensile-strength determinations, also showed the greatest spread in ultimate elongation, though in the latter case the coefficient of variation is not slgnificantly out of line.

\section{SUMMARY AND CONCLUSION}

The toggle clamp described in this paper is adapted to use with a wide range of sizes and types of specimens for the tensile testing of rubber. Tubular and strip specimens, when tested with the new clamp, give values for the tensile strength that are only a little lower than those obtainable with dumbbell specimens of the same composition. The values are considerably higher, however, than those obtained with the roll clamp commonly used. The new clamp, therefore, is particularly suitable for the testing of rubber insulation and other products of such a shape that dumbbells cannot readily be prepared from them.

Acknowledgment is made to E. E. Creitz, who suggested a preliminary design of the toggle clamp.

Washington, February 23, 1939. 